О.А. Дакі, В.М. Іваненко, В.М. Федунов, В.І. Чебан

Державний університет інфраструктури та технологій, Київ

\title{
ПОБУДОВА НЕЧІТКОГО РЕГУЛЯТОРА СТАБІЛІЗАЦІЇ СУДНА НА ТРАЄКТОРІЇ
}

Підвищення точності стабілізації маломірного судна на траєкторії та зниження кількості перекладок руля, щуо підвищує ресурс авторульового, досягається за допомогою нечіткого регулятора, який працює на основі використання досвіду людини-рульового. В статті розроблена структурна схема управління та стабілізації судна на траєкторії, загальна схема управління із застосуванням нечіткого регулятора, а також структурна схема системи управління рухом маломірного судна із нечітким регулятором. Розроблена база правил для нечіткого регулятора та правила виведення, які грунтуються на відомому методі логічного виведення Мамдані. Застосування нечіткого регулятора дозволяє забезпечити зниження кількості перекладок руля суднової рульової машини.

Ключові слова: маломірні морські судна, навігація та управління рухом, нечіткий регулятор, нечіткі множини, стабілізація на траєкторії.

\section{Вступ}

Постановка проблеми. На даний час на суднах морського та річкового флоту, разом з іншими автоматичними системами, находять застосування системи автоматичного управління рухом судна за курсом (авторульові) [1-2]. Ці системи є найбільш важливими та відповідальними системами в судновій автоматиці. Від їх якості та надійності значною мірою залежать надійність мореплавання, а також техніко-економічні показники суден.

Система автоматичного управління при русі судна за курсом вирішує наступні завдання:

- стабілізацію - автоматично тримати судно за заданим курсом;

- маневрування - достатньо точно та швидко виконувати отримані накази (управляючі впливи).

Забезпечення стану безперервної роботи авторульового протягом всього часу плавання судна залежить від надійності його елементів, тому необхідно підбирати в розрахунку також елементи та коригуючі пристрої, які не призводять до надмірної складності системи та зниження іiї надійності. Важливим є обмеження числа перекладок руля при стабілізації на курсі.

Аналіз останніх досліджень і публікацій. Розробка систем управління та методів стабілізації суден на траєкторії є важливим науковим напрямком у галузі навігації та управління рухом. Дослідженню та проектуванню систем автоматичного управління рухом та нечітких регуляторів для морських рухомих об'єктів при стабілізації їх на курсі та на траєкторії, а також проектуванню автоматизованих комплексів судноводіння присвячені роботи Л.Л. Вагущенка, А.А. Кошового, С.П. Дмитрієва,
О.В. Збруцького, А.С. Пелевіна, С.Я. Березіна, Б.О. Тетюєва, Ю.О. Лукомського. Додатково для розкриття змісту даної статті необхідно відмітити роботи $з$ побудови нечітких систем та нечіткої логіки.

Метою статті $\epsilon$ розробка структури та алгоритмів функціонування нечіткого регулятора для стабілізації й управління рухом маломірного судна, що забезпечує зниження кількості перекладок руля суднової рульової машини.

\section{Виклад основного матеріалу}

Для реалізації задачі автоматичної стабілізації судна на курсі найчастіше використовується ПІД регулятор:

$$
\alpha=k_{1} \psi+k_{2} \dot{\psi}+k_{3} \int_{0}^{t} \psi d t,
$$

де $\alpha$ - заданий кут перекладки руля;

$k_{1,2,3}$ - параметри управління;

$\psi$ - відхилення судна від заданого курсу.

Принцип роботи САУ курсом судна показаний на рис. 1 . На рис. 1 позначено: $K_{3}-$ заданий курс судна; $K_{m}$ - поточний курс судна; $\psi-$ відхилення судна від заданого курсу; $\alpha$ - заданий кут перекладки руля; $\beta$ - фактичний кут перекладки руля; $f-$ зовнішні збурення; $M_{c}-$ множина параметрів руху судна. При русі за заданою траєкторією основним регульованим значенням $є$ бічне відхилення центру ваги судна $\eta$ від заданої лінії шляху. Бічне відхилення розраховується відповідно до даних обчислень та показань навігації, що безперервно обчислюють координати судна. 


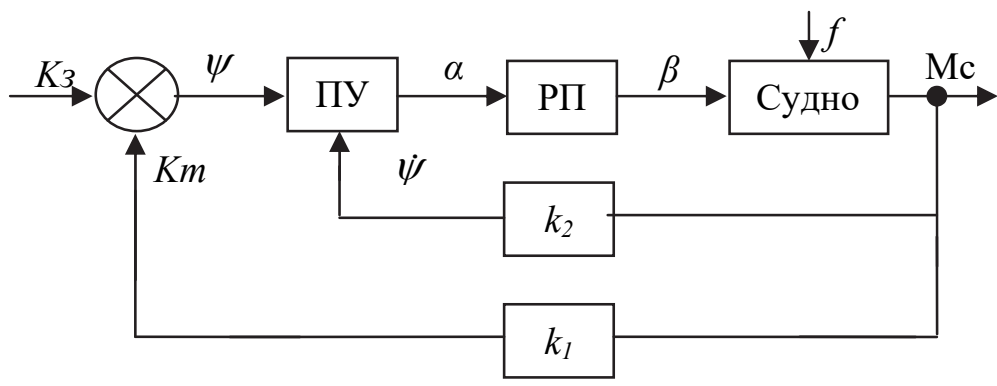

Рис. 1. Структурна схема системи автоматичного управління судном на траєкторії Джерело: [1].

На основі безперервних даних про поточне розташування судна (точка $M$ на рис. 2) система відпрацьовує значення відхилення $\eta$.

Даний маршрут вводиться в систему у вигляді координат початкової та кінцевої точок прямолінійних відрізків потрібної траєкторії, знятих $з$ навігаційної карти.

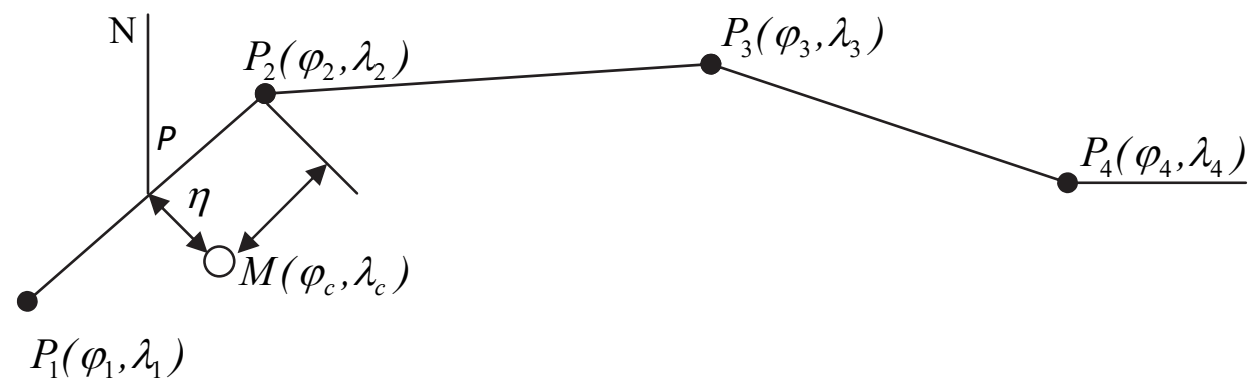

Рис. 2. Принцип стабілізації судна на траєкторії Джерело: розроблено авторами.

Закон контролю в завданні стабілізації за траєкторією побудований у вигляді лінійної функції від $\psi-$ відхилення курсу від кута ходу траєкторії, $\omega_{z}-$ кутової швидкості рискання, $\eta$ - бічного відхилення від траєкторії та інтегралу від нього, що є, по суті, ПІД - регулятор по $\eta$, що представляє собою, по суті, ПІД - регулятор з деяким наближенням як похідна $\eta$. Управління такого ПІД-регулятора на кожний момент дискретного часу визначається наступним співвідношенням:

$$
u_{l}=-\left[s_{1}\left(\psi_{l}-\Delta \psi_{l}\right)+s_{2} \omega_{z l}\right]
$$

де $\Delta \psi_{l}$ - поправка до заданого курсу, яка розраховується за формулою [1]:

$$
\Delta \psi_{l}=s_{3} \eta_{l}+s_{4} \sum_{i=1}^{K} \eta_{i},
$$

де $s_{1,2,3,4}$ - коефіцієнти управління.

Вимірювання координати $\eta$, яке формується за координатами місцеположення - за широтою $\phi_{c}$ та довготою $\lambda_{c}$ (обсерваційні координати) та відомими параметрам локсодромічної ділянки, заданої координатами початкової точки $\phi_{0}, \lambda_{0}$ i курсовим кутом $P$, визначаються формулою (еліптичністю
Землі нехтують) [2]:

$$
\begin{gathered}
\eta=\left\{-\ln \left[\frac{\operatorname{tg} \phi_{c} / 2+\pi / 4}{g \phi_{0} / 2+\pi / 4}\right] \sin P+\left(\lambda_{c}-\lambda_{0}\right) \cos P\right\} \times \\
\times R \cos \left(\frac{\phi_{0}+\phi_{c}}{2}\right),
\end{gathered}
$$

де $R$ - радіус Землі, або спрощеною формулою:

$$
\eta=R \times
$$

$$
\times\left\{\left(\phi_{c}-\phi_{0}\right) \sin P+\left(\lambda_{c}-\lambda_{0}\right) \cos \left(\frac{\phi_{c}+\phi_{0}}{2}\right) \cos P\right\} .
$$

Основні завдання зі стабілізації МС на траєктоpiï. При вирішенні проблеми стабілізації судна на траєкторії управління здійснюється за законом (2). При цьому бічне відхилення розраховується за формулою (5). У формулі (5) значення $\phi_{c}, \lambda_{c}$ визначаються будь-яким відомим методом. Можна зробити висновок, що чим вища точність їх визначення, тим точніше визначається бічне відхилення i, таким чином, забезпечується точна стабілізація судна на траєкторії. Таким чином, при стабілізації судна на траєкторії вирішальним питанням $є$ точне та безперервне визначення місця розташування судна [3-4].

Оптимальний контроль судна, відповідно до даного закону, забезпечується авторульовим на тихій воді та 3 помірними хвилюваннями. Досвід екс- 
плуатації авторульових параметрів показує, що коли хвилюванні більше 3-х балів, необхідне переналаштування параметрів авторульового, оскільки в іншому випадку досягнення зазначеної точності управління супроводжується перевантаженням приводу. При значному хвилюванні зазвичай переходять на ручне управління, при якому людина - рульовий за своїм дослідом виробляє ступінчасті перекладки руля при значних відхиленнях судна від траєкторії. Цим досягається зменшення кількості перекладок руля та забезпечення надійності роботи рульового приводу та збільшення ефективності управління [56]. У зв'язку з цим завданню зменшення кількості перекладок руля при автоматичному утримування судна на курсі та на траєкторії в умовах хвильового збурення приділяється багато уваги. У роботах [7-9] для усунення високочастотного компонента сигналу управління, викликаного хвилюванням, тобто для зменшення кількості перекладок руля, пропонується представляти курс та кутову швидкість рискання у вигляді двох компонентів: повільного, що характе- ризує рух судна під впливом управління та повільних збурень.

3 розвитком теорії нечітких множин та нечіткої логіки [10-12] є можливість поліпшити АР на базі використання нової системи управління елементом базових - нечітких регуляторів.

При роботі такі регулятори функціонують за спеціальними правилами в базі знань, яка базується на використанні досвіду людини-оператора та підлаштовує свою поведінку при управлінні об'єктами.

Нечітка логіка, як нова галузь математики, була представлена в 60-х роках професором Каліфорнійського університету Лотфі Заде [10]. Спочатку він був розроблений як засіб моделювання невизначеності природної мови, але спектр завдань, в яких нечітка логіка знайшла застосування значно розширився. Інтуїтивна простота нечіткої логіки як методології вирішення проблем гарантує успішне використання в системах управління різного призначення. Принципова структура системи управління 3 нечітким регулятором показана на рис. 3.

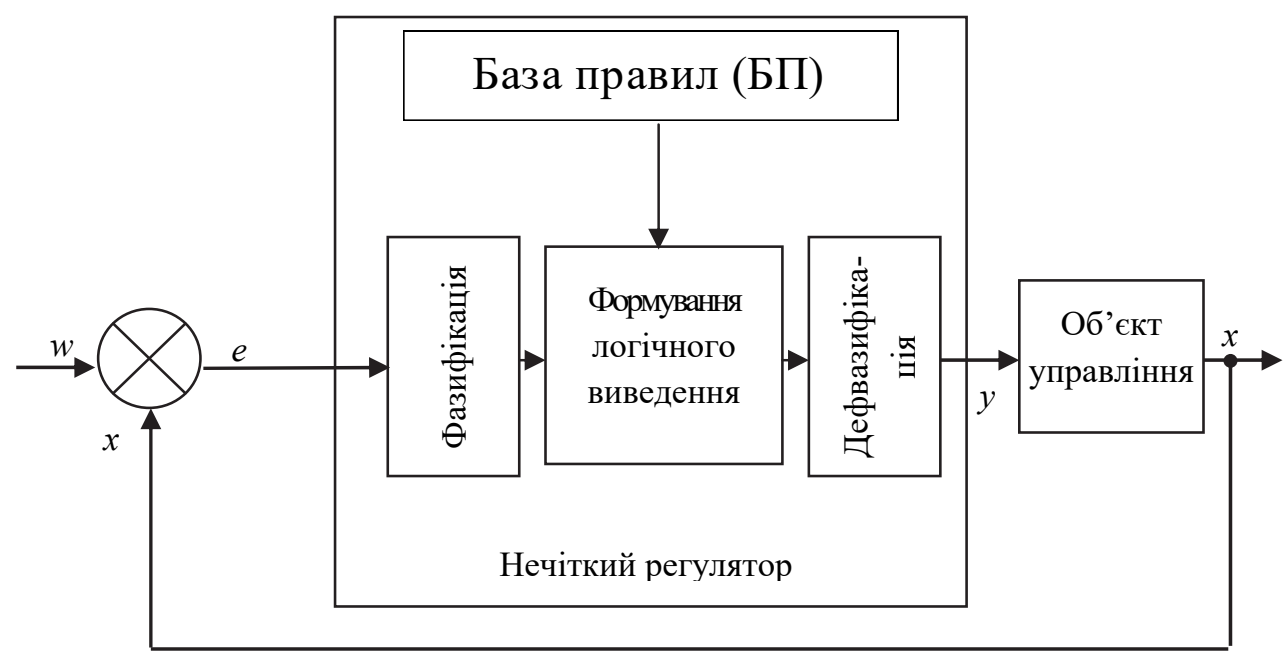

Рис. 3. Загальна структура схеми управління з нечітким регулятором Джерело: розроблено авторами.

На рис. 3 позначено: $w$ - вплив; $e$ - відхилення регульованої величини; $y$ - управляюча дія; $x$ регульована величина; база правил (БП) - це сімейство емпіричних знань про процес у вигляді ряду продукційних правил типу “якщо” - “то”.

Блок фазифікації перетворює чіткі значення, виміряні при вході об'єкта управління, на нечіткі значення, описані лінгвістичними змінними в основі правил. Блок рішень використовує нечіткі умовні правила “якщо” - “то”, вбудовані в базу знань, для перетворення нечіткого виведення в необхідні контрольні впливи, які також нечіткі. Блок дефазифікації перетворює нечіткі величини, які використовуються для управління об'єктом.

У технічних системах нечіткі регулятори використовуються для управління складними процесами, коли немає простої математичної моделі, нелінійні процеси високого порядку, а також, коли необхідно виробляти обробку лінгвістично сформульовані експертні знання.

На рис. 4 наведена структурна схема системи управління рухом судна на основі нечіткого регулятора. При управлінні судном рульовий стежить за відхиленням судна від заданого курсу (траєкторії) та за кутовою швидкістю повороту судна і відкладає кут перекладки руля відповідно до цих величин так, щоб судно виходило на заданий курс із максимальною точністю.

При хвилюванні моря рульовий буде реагувати тільки на значні відхилення, тим самим обмежується кількість перекладок руля, що підвищується ресурс служби авторульового. 


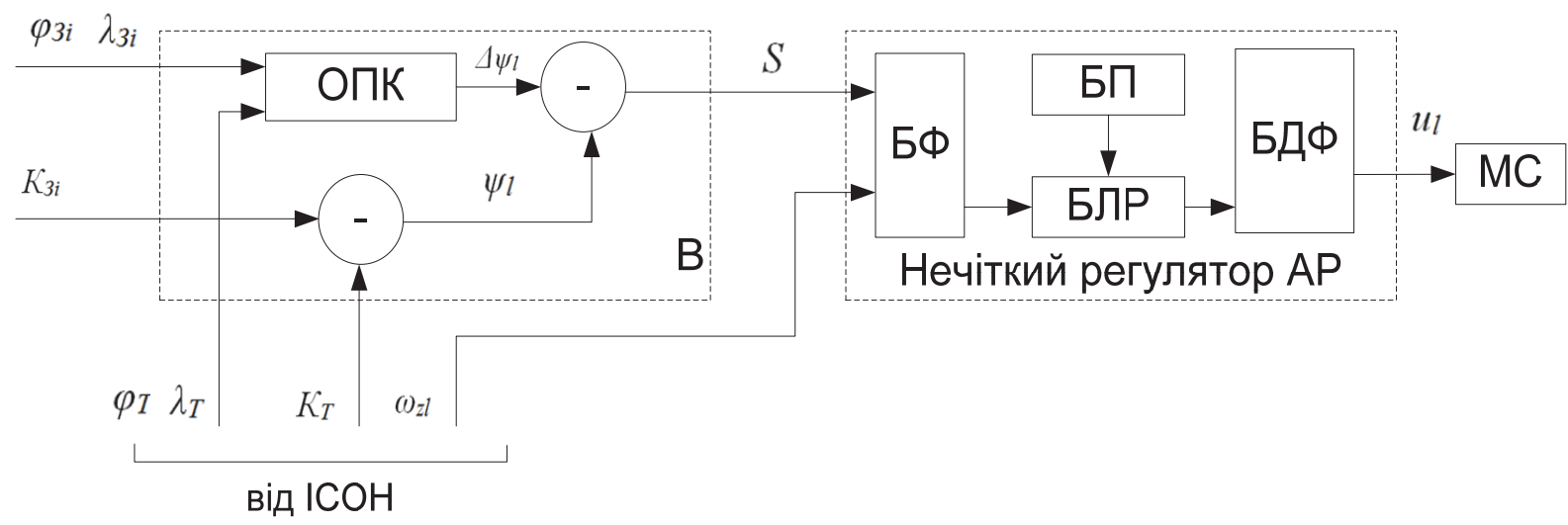

Рис. 4. Структурна схема системи управління рухом маломірним судном із нечітким регулятором Джерело: розроблено авторами.

На рис. 4 позначено: $K_{3 i}$ - заданий курс; $K_{T}$ поточний курс; $\varphi_{3 i}, \lambda_{3 i}, \varphi_{T}, \lambda_{T}-$ задані та поточні координати МС; БФ - блок фазифікації; БП - база правил; БЛР - блок логічного рішення; БДФ - блок дефазифікації; $M_{m}$ - множина поточних параметрів $\mathrm{MC}$; ОПК - обчислювач поправки до заданого курсу $u_{i}$. Для нечіткого регулятора системи управління рухом судна в якості першої вхідної змінної приймаємо сумарне відхилення поточного курсу судна від заданого $\psi_{l}$ та похибки до цієї величини за рахунок бічного відхилення МС від траєкторії $\Delta \psi_{l}\left(S=\psi_{l}-\Delta \psi_{l}\right)$, а в якості другої вхідної змінної приймемо кутову швидкість повороту судна $\omega_{z l}$, за вихідну змінну приймаємо кут перекладки руля $\alpha$.
Назвемо їх відповідно - Відхилення, Кутова швидкість та Кут перекладки руля.

Закон управління задамо у вигляді бази правил, розробленої з урахуванням досвіду управління маломірним судном в умовах морського хвилювання. Сутність такого керування складається у фільтрації малих значень $S$ та $\omega_{z l}$, а також у східчастому відхиленні руля, що значно знижує кількість його перекладань. Для змінної “Відхилення” пропонується використовувати сім термів: негативне велике (НВ); негативне середнє (НС); негативне мале (НМ); нуль (Н); позитивне мале (ПМ); позитивне середнє (ПС); позитивне велике (ПВ). Значення функції приналежності (ФП) змінної “Відхилення” задаються графіком на рис. 5.

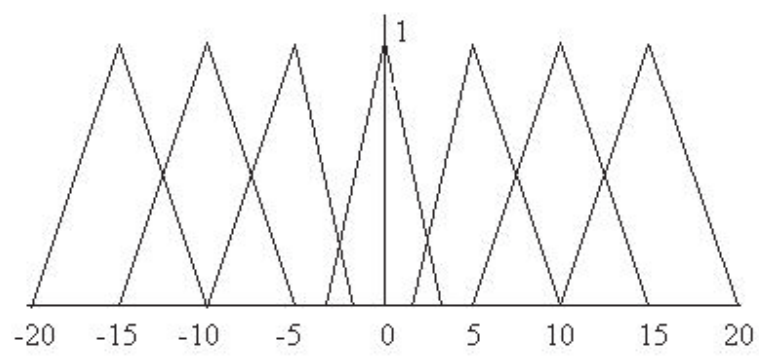

Рис. 5. Функція приналежності змінної Відхилення $\left(S,{ }^{\circ}\right)$

Джерело: розроблено авторами.

Для другої вхідної змінної “Кутова швидкість” пропонується до використання сім термів: негативно велика (НВ); негативна середня (НС); негативна мала (НM); нуль (Н); позитивна мала
(ПМ); позитивна середня (ПС); позитивна велика (ПВ).

Значення функції приналежності задаються графіком на рис. 6 .

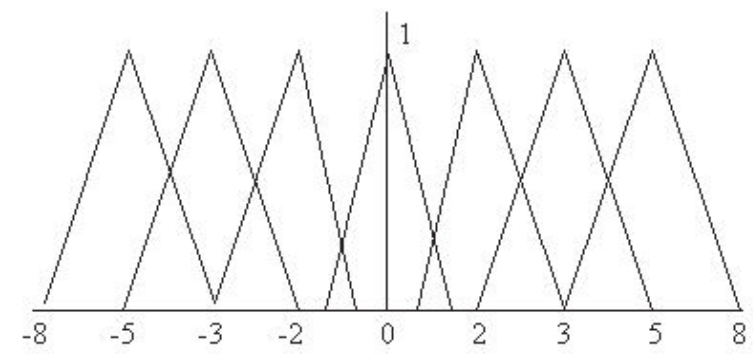

Рис. 6. Функція приналежності змінної Кутова швидкість $\left(\omega_{z l}, \%\right.$ c) Джерело: розроблено авторами. 
Для вихідної змінної “Кут перекладки руля" також пропонується сім термів:

- негативний великий (HB); негативний середній (НС); негативний малий (НМ); нуль (Н0); пози- тивний малий (ПМ); позитивний середній (ПС); позитивний великий (ПВ).

Значення функції приналежності задаються графіком на рис. 7.

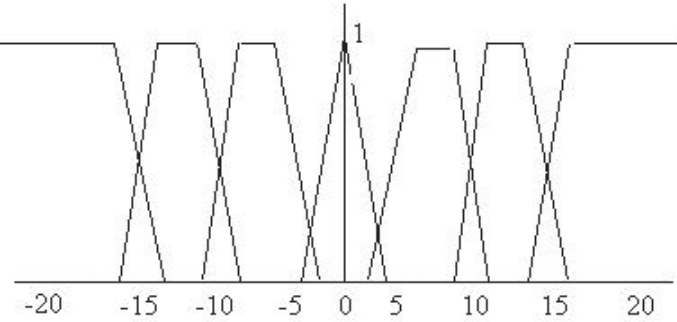

Рис. 7. Функція приналежності вихідної змінної Кут перекладки руля $\left(\alpha,{ }^{\circ}\right)$

Джерело: розроблено авторами.

Задамо правила у вигляді матриці, значення якої задаються в табл. 1. Рядки матриці відповідають вхідній змінній Відхилення. Стовпці матриці відповідають вхідній змінній Кутова швидкість. Значення матриці відображають значення вихідний змінної Кут перекладки руля.

Таблиця 1

База правил нечіткого регулятора

\begin{tabular}{|c|c|c|c|c|c|c|c|c|}
\hline & \multicolumn{7}{|c|}{ Кутова швидкість $\left(\omega_{z l}\right)$} \\
\hline & & HB & $\mathrm{HC}$ & HM & НУЛЬ & ПМ & $\Pi$ ПC & ПВ \\
\hline \multirow{7}{*}{$\begin{array}{l}\sqrt{2} \\
\frac{\pi}{2} \\
\frac{5}{2} \\
\frac{\pi}{0} \\
0\end{array}$} & HB & НУЛЬ & HM & $\mathrm{HC}$ & $\mathrm{HB}$ & $\mathrm{HB}$ & $\mathrm{HB}$ & $\mathrm{HB}$ \\
\hline & HC & $\Pi \mathrm{M}$ & НУЛЬ & HM & $\overline{\mathrm{HC}}$ & $\mathrm{HB}$ & HB & HB \\
\hline & HM & ПС & ПМ & НУЛЬ & HM & $\mathrm{HC}$ & HB & HB \\
\hline & НУЛЬ & ПВ & $\Pi \mathrm{\Pi C}$ & ПМ & НУЛЬ & HM & $\mathrm{HC}$ & HB \\
\hline & ПМ & $\overline{\Pi B}$ & ПВ & ПС & ПM & НУЛЬ & $\mathrm{HM}$ & $\mathrm{HC}$ \\
\hline & $\Pi \mathrm{\Pi C}$ & $\overline{\Pi \Pi}$ & $\Pi$ ПВ & ПВ & ПС & $\overline{\Pi M}$ & 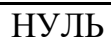 & HM \\
\hline & ПВ & $\overline{\Pi B}$ & ПВ & ПВ & ПВ & $\overline{\Pi \Pi C}$ & ПМ & НУЛЬ \\
\hline
\end{tabular}

Джерело: розроблено авторами.

Для здійснення логічного виведення застосуємо алгоритм Мамдані [12]. Процес виведення здійснюється за такими етапами: 1. Нечіткість: для значень вхідних перемінних знаходяться ступені істинності для передумов кожного правила. Для обчислення ступеня істинності вхідних перемінних вве- демо наступні позначення абсцис вузлових точок для функції приналежності трапецеїдальної форми (рис. 8): де $l$ - координата самої лівої точки трапеції; $m l$ - координата лівої середньої точки трапеції; $m r$ - координата правої середньої точки трапеції; $r$ - координата самої правої точки трапеції.

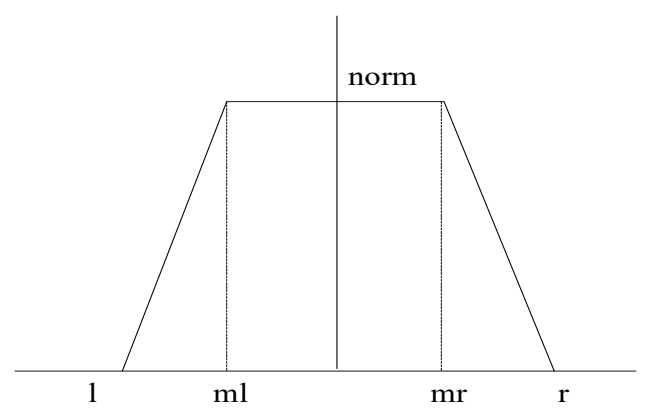

Рис. 8. Вузлові точки трапециїдальної функції приналежності Джерело: розроблено авторами.

Тоді трикутну функцію приналежності можна записати у вигляді:

$$
M F(x, n o r m, l, m l, m r, r)=\mid \begin{aligned}
& \left.\frac{n o r m}{m l-l}(x-l)\right] \text { if }(x \geq l) .(x \leq m l) .(l \neq m l), \\
& \text { norm if }(x \geq m l) .(x \leq m r), \\
& {\left[\begin{array}{l}
\frac{n o r m}{r-m r}(r-x) \\
r-i f(x \geq m r) .(x \leq r) .(m r \geq r), \\
0 \text { otherwise, }
\end{array}\right.}
\end{aligned}
$$


де $x$ - поточна координата; norm - верхня границя (координата $y$ ) функції приналежності.

Для реалізації обчислення приведемо функції приналежності змінних у форму матриць:

$$
X 1=\left[\begin{array}{cccc}
-20 & -15 & -15 & -10 \\
-15 & -10 & -10 & -5 \\
-10 & -5 & -5 & -3 \\
-5 & 0 & 0 & 5 \\
3 & 5 & 5 & 10 \\
5 & 10 & 10 & 15 \\
10 & 15 & 15 & 20
\end{array}\right]
$$

$$
\begin{aligned}
X 2 & =\left[\begin{array}{cccc}
-8 & -5 & -5 & -3 \\
-5 & -3 & -3 & -2 \\
-3 & -2 & -2 & -1 \\
-1,5 & 0 & 0 & 1,5 \\
1 & 2 & 2 & 3 \\
2 & 3 & 3 & 5 \\
3 & 5 & 5 & 8
\end{array}\right] ; \\
O U T & =\left[\begin{array}{cccc}
-40 & -30 & -20 & -17 \\
-20 & -17 & -15 & -10 \\
-15 & -10 & -5 & -3 \\
-5 & 0 & 0 & 5 \\
3 & 5 & 10 & 15 \\
10 & 15 & 17 & 20 \\
17 & 20 & 30 & 40
\end{array}\right] .
\end{aligned}
$$

2. Нечітке виведення: знаходяться рівні “відсі- кання” для передумов кожного $з$ правил (з використанням операції $\mathrm{min})$ :

$$
\operatorname{koef}\left(i, j, x_{1}, x_{2}\right)=\operatorname{and}\left(Y_{1}\left(i, x_{1}\right), Y_{2}\left(j, x_{2}\right)\right),
$$

де $Y_{1}\left(i, x_{1}\right)=\operatorname{MF}\left(x_{1}, 1, X 1_{i, 1}, X 1_{i, 2}, X 1_{i, 3}, X 1_{i, 4}\right)$,

$$
Y_{2}\left(j, x_{2}\right)=M F\left(x_{2}, 1, X 2_{j, 1}, X 2_{j, 2}, X 2_{j, 3}, X 2_{j, 4}\right),
$$
$i=1$. parts $1, j=1$.. parts 2 - номер терми першої і другий вхідний змінної відповідно; parts1 $=7$, parts 2 $=7-$ кількість терм.

Якщо позначити кожну ділянку функції приналежності вихідної змінної числами (від 1 до 7), то таблицю бази правил можна записати у вигляді такої матриці, в якій кожному рядку відповідає ділянка функції приналежності першої вхідний змінної $X 1$, кожному стовпцю відповідає ділянка функції приналежності другої вхідної змінної $X 2$, а на перетинанні рядка й стовпця знаходиться номер ділянки функції приналежності вихідної змінної OUT, що відповідає даному правилу.

$$
\text { RULES }=\left[\begin{array}{lllllll}
4 & 3 & 2 & 1 & 1 & 1 & 1 \\
5 & 4 & 3 & 2 & 1 & 1 & 1 \\
6 & 5 & 4 & 3 & 3 & 1 & 1 \\
7 & 6 & 5 & 4 & 3 & 2 & 1 \\
7 & 7 & 6 & 5 & 4 & 3 & 2 \\
7 & 7 & 7 & 6 & 5 & 4 & 3 \\
7 & 7 & 7 & 7 & 6 & 5 & 4
\end{array}\right] .
$$

3. Композиція: $з$ використанням операції $\max$ виконує об'єднання знайдених усічених функцій, що призводить до отримання нечіткої підмножини для змінної виходу з функцією приналежності:

$$
y\left(z, x_{1}, x_{2}\right)=\sum_{i=1}^{\text {parts } 1} \sum_{j=1}^{\text {parts } 2} M F\left(z, \operatorname{koef}\left(i, j, x_{1}, x_{2}\right), \text { OUT }_{\text {rules }_{i, j}, 1}, \text { OUT }_{\text {rules }_{i, j}, 2}, \text { OUT }_{\text {rules }_{i, j}, 3}, \text { OU }_{\text {rules }_{i, j}, 4}\right) .
$$

4. Приведення до чіткості: виконується центроїдним методом:

$$
C\left(x_{1}, x_{2}\right)=\frac{\sum_{z=-20}^{20}\left[y\left(z, x_{1}, x_{2}\right) z\right]}{\sum_{z=-20}^{20} y\left(z, x_{1}, x_{2}\right)} .
$$

Таким чином, використання даного алгоритму дозволяє отримати чітке значення для стабілізації судна на траєкторії.

\section{Висновки}

При стабілізації судна по траєкторії маршрути руху вводяться до інформаційно-навігаційної систе- ми та зберігаються в базі даних.

Виходячи $з$ інформації про поточне місцезнаходження маломірного судна 3 підвищеною точністю за допомогою інтегральної системи орієнтації та навігаціï, а також даних про маршрути в базі даних, генерується контрольний сигнал, який потім подається на авторульовий пристрій 3 нечітким регулятором для управління руху судна відповідно до зазначеного закону.

В статті розроблена структура та алгоритм функціонування нечіткого регулятора для стабілізації й управління рухом маломірного судна, що забезпечує зниження числа перекладок руля суднової рульової машини.

\section{Список літератури}

1. Дмитриев С. П., Пелевин А. Е. Задачи навигации и управления при стабилизации судна на траектории. СанктПетербург : Электроприбор, 2002. 160 с.

2. Вагушенко Л. Л. Автоматизация судовождения. Одесса: ОГМА, 1994. 355 с.

3. Fossen T. I. Guidance and Control of Ocean vehicles. Chichester : John Wiley \& Sons Ltd. 1994. 480 p.

4. Holzhuter T. A High Precision Track Controller for Ships. 11th IFAC Wold Congress, 1990. Vol. 8. P. 118-123. 
6. Holzhuter T. LQC Approach for the High-Precision Track Control of Ship. IEEE Proc. Control Theory Application. 1997. Vol. 144 (2). P. 121-127.

7. Блинцов В. С., Фан В. В. Задачи совершенствования информационно-управляющих систем для малоразмерных скоростных судов. Збірник наукових праць національного університету кораблебудування. 2002. № 7(385). С. 140-146.

8. Правила класифікації та побудови морських суден. Том.1. Київ : РСУ, 2002. 368 с.

9. Гостев В. И. Синтез нечетких регуляторов систем автоматического управления. Київ : Радіоаматор, 2003. 512 с.

10. Нечеткие множества в моделях управления и искусственного интеллекта / под. ред. Д. А. Поспелова. Москва : Наука, 1986. 312 с.

11. Конышева Л. К., Назаров Д. М. Основы теории нечетких множеств. Санкт-Петербург : Питер, 2011. 192 с.

12. Алтунин А. Е., Семухин М. В. Модели и алгоритмы принятия решений в нечетких условиях : монография. Тюмень : ТГУ, 2000. 352 с.

Надійшла до редколегії 05.05.2021

Схвалена до друку 13.07.2021

\section{Відомості про авторів:}

\section{Дакі Олена Анатоліївна}

доктор технічних наук доцент

директор Дунайського інституту водного транспорту

Державного університету інфраструктури та технологій

Київ, Україна

https://orcid.org/0000-0003-3932-462X

\section{Іваненко Віталій Миколайович}

старший викладач

Державного університету інфраструктури та технологій Київ, Україна

https://orcid.org/0000-0003-3271-5257

\section{Федунов Валерій Миколайович}

асистент

Державного університету інфраструктури та технологій Київ, Україна

https://orcid.org/0000-0001-5092-2511

\section{Чебан Валерій Іларіонович}

старший викладач

Державного університету інфраструктури та технологій Київ, Україна

https://orcid.org/0000-0001-9662-8617

\section{Information about the authors:}

\section{Olena Daki}

Doctor of Technical Sciences Associate Professor

Director of Danube Institute of Water

State University of Infrastructure and Technologies

Kyiv, Ukraine

https://orcid.org/0000-0003-3932-462X

\section{Vitaliy Ivanenko}

Senior Lecturer

State University of Infrastructure and Technologies, Kyiv, Ukraine

https://orcid.org/0000-0003-3271-5257

\section{Valeriy Fedunov}

Assistant Lecturer

State University of Infrastructure and Technologies

Kyiv, Ukraine

https://orcid.org/0000-0001-5092-2511

\section{Valeriy Cheban}

Senior Lecturer

State University of Infrastructure and Technologies

Kyiv, Ukraine

https://orcid.org/0000-0001-9662-8617

\title{
ПОСТРОЕНИЕ НЕЧЕТКОГО РЕГУЛЯТОРА СТАБИЛИЗАЦИИ СУДНА НА ТРАЕКТОРИИ
}

\author{
Е.А. Даки, В.Н. Иваненко, В.Н. Федунов, В.И. Чебан
}

Повышение точности стабилизации маломерного судна на траектории и снижение количества переложений руля, что повышает ресурс авторулевого, достигается с помощью нечеткого регулятора, который работает на основе использования опыта человека-рулевого. В статье разработана структурная схема управления и стабилизачии судна на траектории, общая схема управления с применением нечеткого регулятора, а также структурная схема системь управления движением маломерным судном с нечетким регулятором. Разработана база правил для нечеткого регулятора и правила вывода, основанные на известном методе логического вывода Мамдани. При стабилизации судна по траектории, маршруты движения вводятся в информационно-навигационную систему и хранятся в базе данных. Исходя из информации о текущем местоположении маломерного судна с повышенной точностью с помощью интегральной системы ориентации и навигации, а также данных о марирутах в базе данных, генерируется контрольный сигнал, который затем подается на авторулевое устройство с нечетким регулятором для управления движения судна в соответствии с указанным законом. В статье разработана структура и алгоритм функиионирования нечеткого регулятора для стабилизаиии и управления движением маломерного судна, который обеспечивает снижение количества переложений руля судовой рулевой машинь.

Ключевые слова: маломерные морские суда, навигация и управление движением, нечеткий регулятор, нечеткие множества, стабилизаиия на траектории. 


\section{CONSTRUCTION OF A FUZZY VESSEL STABILIZATION REGULATOR ON A TRAJECTORY}

O. Daki, V. Ivanenko, V. Fedunov, V. Cheban

An increase in the accuracy of stabilization of a small vessel on the trajectory and a decrease in the number of rudder movements, which increases the resource of the autopilot, is achieved with the help of a fuzzy regulator, which works on the basis of using the experience of a person at the helm. The article develops a structural diagram of control and stabilization of a vessel on the trajectory, a general control scheme using a fuzzy regulator, as well as a structural diagram of a traffic control system for a small vessel with a fuzzy regulator. For the fuzzy regulator of the ship's motion control system as the first input variable we take the total deviation of the current course of the ship from the set and the error to this value due to the lateral deviation of the MS from the trajectory. As the second input variable we will accept angular speed of turn of the vessel; for the output-bottom variable we take the angle of the rudder. Let's call them respectively - Deviation, Angular velocity and Steering angle. The law of management will be set in the form of the base of rules developed taking into account experience of management of the small vessel in the conditions of sea excitement. The essence of such control consists in filtering of small values, and also in a step deviation of a wheel that considerably reduces quantity of its transfers. A rule base for a fuzzy regulator and inference rules based on the well-known Mamdani inference method have been developed. When the vessel is stabilized along the trajectory, the movement routes are entered into the information and navigation system and stored in the database. Based on information about the current location of the small vessel with increased accuracy using the integrated attitude and navigation system, as well as data on routes in the database, a control signal is generated, which is then fed to the fuzzy autopilot device to control the movement of the vessel in accordance with specified by law. The article develops a structure and an algorithm for the functioning of a fuzzy regulator for stabilizing and controlling the movement of a small vessel, which ensures a decrease in the number of rudder shifts of the ship's steering gear.

Keywords: small ships, navigation and traffic control, fuzzy controller, fuzzy sets, trajectory stabilization. 